\title{
SONATAS № 2 END № 9 AS MILESTONES IN THE EVOLUTION OF THE PIANO STYLE OF A. SCRIABIN
}

N. S. Lebedeva. Sonatas № 2 end № 9 as Milestones in the Evolution of the Piano Style of A. Scriabin

The article is devoted to the consideration of two piano sonatas by A. Scriabin, representing in a complex the peculiarities of his piano style as an integral phenomenon. The two-part sonata No. 2, classified as a musical landscape, is considered in comparison with the performing versions proposed by S. Richter and V. Ashkenazy. The one-part Sonata No. 9, called "Black Mass", is considered in comparison with the performing interpretations of V. Sofronitsky and V. Horowitz.

It is noted that the Scriabin's piano style is inherently mixed, compositional and performing, and its grandiose macrocycle of 10 sonatas appears as a compendium of the principles of piano thinking for the post-romantic era. The universalism of Scriabin's writing is confirmed using the comparative method of analysis, for the first time proposed in this article in relation to the works under consideration.

It was revealed that the style in music appears as "a system of stable features of musical phenomena, a way of their differentiation and integration at various levels" (S. Tyshko). The style is distinguished by a tendency to identify the individual, unique, "humanistic" in the broad sense of the word and has a hierarchical structure, within which there is a level characterized as "the style of any kind of music" (V. Kholopova), among which the piano style stands out.

Scriabin's piano sonatas combine the categories of "instrument style", "author's style" and "performer's style" at the style level.

It was revealed that the figurative and artistic duality of the Second sonata is reflected in the interpretations presented by S. Richter (the "classical" version, focused on the exact observance of the author's text remarques, sounding in some places even like in Beethoven's works), and V. Ashkenazy (the "romantic" version containing a whole complex of articulatory means added by the performer, most of all close to Chopin's "sonic placers").

The main factor that determines the peculiarities of the performance of the Ninth sonata is the transfer of the playing of harmonic timbre-colors, in which the melodic horizontal turns out to be inert in itself and manifests itself only in harmonic lighting in combination with articulatory attributes. It is noted that A. Scriabin creates in the Ninth sonata actually a special type of texture, accentuating the parameter of depth, based on the stereophonic effect "further closer".

In the conclusions on the article, it is noted that the stylistic "arch" of two Scriabin's sonatas highlighted in it helps to comprehend the holistic character and contextual connections of the sonata-piano style of the great Russian composer-innovator, to find "keys" to actual interpretations of his other piano sonatas, an example of which is analyzed interpretation samples of such masters as V. Sofronitsky and V. Horowitz (Ninth sonata) and S. Richter and V. Ashkenazy (Second sonata)

Keywords: piano sonata, sonata-fantasy, sonatapoem, A. Scriabin, sonata-piano style of A. Scriabin.

H. С. Лебедєва. Сонати № 2 та № 9 як віхи на шляху еволюції фортепіанного стилю О. Скрябіна

Актуальність. Статтю присвячено розгляду двох фортепіанних сонат О. Скрябіна. Двочастинна Соната № 2, що класифікується як музичний пейзаж, розглядається в порівнянні виконавських версій С. Ріхтера та В. Ашкеназі. Одночастинна Соната № 9, яка дістала назву «Чорна Меса», розглядається у виконавських інтерпретаціях В. Софроницького та В. Горовиця.

Мета статті. За допомогою компаративного методу аналізу, уперше застосованого в цій статті стосовно творів О. Скрябіна, підтвердити універсальність скрябінського письма.

Результати. Розгляд двох фортепіанних сонат О. Скрябіна, які в комплексі репрезентують особливості його фортепіанного стилю як цілісного феномену, засвідчив, що скрябінський фортепіанний стиль за своєю природою є змішаним, композиторсько-виконавчим. Зазначено: його грандіозний макроцикл з 10 сонат постає як компендіум принципів фортепіанного мислення, характерних для постромантичної доби.

Висновки. Скрябінське письмо є універсальним, композиторсько-виконавчим, що підтверджується компаративним аналізом.

Ключові слова: фортепіанна соната, соната-фантазія, соната-поема, О. Скрябін, сонатно-фортепіанний стиль О. Скрябіна.

Problem statement. O. Scriabin is one of the artists whose philosophical and worldview ideas were directly embodied in their works. 
O. Scriabin's musical thinking is realized in the form of "hearing consciousness" or "auditory consciousness" (Cherednichenko, 1993, p. 40). The main instrument of the latter for O. Scriabin as a composer-pianist was the piano, for which a grandiose cycle of 10 sonatas was created, reflecting the eternal idea of a global universe at the level of a new piano style, which influenced all subsequent development of piano art. O. Scriabin's sonatas are not a "museum exhibit", but fertile material for performing interpretations, in which the intentions of the author of the music and the creator of its sound version must merge. In this context, this article examines the Second and the Ninth sonatas, between which an "arched" stylistic connection is established as a movement from romantic landscape to mysterious sound symbolism, transformed in different ways by outstanding pianists of the XX century.

Relation to scientific and practical problems. Despite the quite complete state of knowledge of the Scriabin's piano style, his sonatas each time open up new facets in the field of content and form for researchers and performers. The tasks of a scrupulous performing analysis of individual sonatas as components of an integral macrocycle arise, which is the main task of this article. In practical terms, such an analysis, including variants of outstanding performing interpretations, can be useful both for concert pianists and for those who are just mastering the secrets of performing skills at the piano faculties of conservatories and departments of music schools.

Analysis of the recent researches and publications. The O. Scriabin's piano style, represented by his sonatas, is characterized in general terms in the works of L. Gakkel (1988) and V. Rubtsova (1989). From the point of view of the theory of texture, A. Skryabin's piano music is analyzed in S. Pankratov's thesis (1977), and in a broader stylistic context, as the property of world pianism of the contemporary times, in the study of V. Dragulian (2009) and in the article of I. Razumeiko (2007). At the same time, the integral characteristics of the compositional and performing features of the sonata-piano heritage of A. Scriabin in a concentrated form has not yet been given, which is the aspect of the scientific novelty of the proposed article.

The purpose of the article is to determine the regularities of O. Scriabin's sonata-piano style on the example of the analysis of two milestone sonatas - two-part Second and one-part Ninth (including a comparative analysis of their outstanding performances).

Presentation of the main research material. Before proceeding to the consideration of specific material, it is necessary to refer to the terminology presented in the title of this article. We are talking about the concept of "style", which reflects its specificity in relation to music and, in particular, the genre of the piano sonata.

Basing on one of the newest definitions of the concept of "musical style" proposed by S. Tyshko, let us designate the following features of this phenomenon:

1) style is a factor of unification or differentiation of musical phenomena, a kind of their identification mark;

2 ) in the concept of style, the integrative and differentiating functions are in relative equilibrium;

3) style is a multilevel phenomenon, which is characterized by an internal hierarchy (from individual style to historical);

4) style has a "joint" concept between form and content.

Bringing these lines of research in music into a single definition, S. Tyshko suggests understanding musical style as "a system of stable features of musical phenomena, a way of their differentiation and integration at various levels (author's individuality, direction and school, historical era, national specificity, etc.), the transition of their semantic fields into specific systems of musical - expressive means" (Tyshko, 1993, p.4).

At the center of the concept of a musical style is the personality of its bearer - the composer, as well as the performer as a co-author of his music, which corresponds to the axiom of J. Buffon: "Style is a person". In music, this is realized in a sound form and presupposes the presence of predicates - "who's style", "what kind of style", "style of what", that is realized in the system of specific styles, according to V. Kholopova, "styles of any kinds of music" (Kholopova, 2000, p. 223), which include the piano music in his interpretation in the sonata genre, proposed by A. Scriabin and outstanding performers of his piano sonatas. As a result, the concept of a sonatapiano style is formed, in which the "image" of an instrument in its timbre and technical characteristics is "strung" together on the genre 
of a chamber sonata, taking into account its constant and variable features, which change their ratio under the influence of the individual styles of composers and performers.

To this it is necessary to add also the O. Scriabin's predicate, which in this case is fundamental. According to B. Asafiev, his style is "the highest stage in the evolution of Russian sonata during the twenty years of 1893-1913; "Emotionally effective, dramatically contrasting symphonism finds a new embodiment here, becomes more sublime and spiritual - the state that can be called poemity..." (Asafiev, 1930, p. 282).

The characteristic given by B. Asafiev is common for O. Scriabin's sonata-piano style, but does not cover the intra-stylistic tendencies contained in it, most clearly presented in the comparison of the early Second and late Ninth sonatas taken in this article.

The Second sonata, designated by the author as op.19, despite its fame and performance, has not yet been stylistically analyzed. The authors of its analytical descriptions (B. Asafiev, A. Alschwang, V. Delson, E. Meskhishvili) turn their attention to the composition and figurative content, leaving as if behind the scenes questions about the Scriabin's pianism, embodied in this work as an example of the romantic style.

Summing up the statements of the abovementioned authors, it should be noted, first of all, the lyrical orientation of the Second sonata, combined with dramatic impetuosity and transparent serenity (Alschwang, 1973, p.96). The history of its creation, which dragged on for almost five years - from 1892 to 1897, is also indicative. The second part (Presto) was composed in Italy, in Genoa, and the first (Andante) - in the Crimea. In 1900 for this Sonata and six preludes op.13 the author was awarded the Prize of M. Glinka. It is also known that the Sonata exists in two author's versions, and in the first of them the author himself performed it in Paris in 1896.

In the final version, A. Scriabin prefaced the Sonata with the subtitle "sonata-fantasy", indicating the combination of the classical canon and romantic freedom in it. The essay is based on an unpublished program by the author, in which he himself, in a conversation with Y. Engel, characterized the $1^{\text {st }}$ part as "a quiet southern night on the seashore", in development - "a dark waving sea", E-dur - E-dur episode "Caressing moonlight after dark"; $2^{\text {nd }}$ part in the figurative plan is more integral - it is "a wide, stormy watery waste” (Delson, 1961, p. 16).

The name "sea", which took root behind the Second sonata, does not mean landscape, but symbolizes the eternal fluidity of being, vague romantic emotional impulses, which is reflected even in the choice of the dis-moll tonality, in the O. Scriabin's tonal symbolism, which acts as the "upper opening" to Fis-dur - the central highaltitude position of this system, symbolizing peace, transparency, serenity. Dis-moll according to O. Scriabin, creates the effect of "receding into the distance", while simultaneously fixing positional fingering, which is convenient for the pianist, about which F. Chopin spoke in his "Method".

Compositionally, the first part of the Second sonata is a complete sonata form. It is based on a short motive-signal, a leit-topic, close, according to A. Alschwang (Alschwang, 1973, p. 97), to the themes of "will" in the later piano works of A. Scriabin. It is characteristic that the use of the leit-motif brings the style of the Second sonata closer not to F. Chopin, but to R. Schumann, about which B. Asafiev wrote, considering the early A. Scriabin to be more a "Schumannist" than a "Chopinist" (Asafiev, 1930, p. 230).

From the "signal" of the leit-topic, the main part is born, the intonations of which are gradually transformed by a derivative contrast that develops into the theme of the side part, given in the key of $H$-dur. The nature of this theme, set forth in a texture similar to P. Tchaikovsky's piano writing (theme-melody in the middle voice), is defined as "refined, graceful, capricious, elusive" (Meskhishvili, 1981, p. 37). This theme should be performed accordingly, which is reflected in V. Ashkenazy's version, where the pianist fully adheres to the interpretation of K. Igumnov, who played this Sonata to O. Scriabin himself. The entire theme of the side part is played, according to this version, on a retarded pedal, which is turned off only in the final imitations. The material of the exposition is summarized in the final part, provided with the author's remark ben markato il canto and reproducing the texture close to Chopin's nocturnes.

This is followed by a development that introduces a figurative contrast, but logically follows from the material of the exhibition. Here it is important for the performer to be able to switch to a new emotional-figurative 
state without going beyond the picture. It is known that A. Scriabin himself resorted in the development to the acceleration of the tempo and acute accentuation, but avoided the sonority of fortissimo, maintaining "the softness of the general color, without interrupting it anywhere" (Delson, 1961, p. 18).

The development sounds the same interpretational way in the performance of V. Sofronitsky and S. Richter. The choice of tempo logic is also important here - Andante should not go into Allegro, which these performers take into account in their interpretations of the development, especially since it is followed by an episode in $E$-dur - "caressing moonlight after dark" (from the author's oral program), solved in the texture of Chopin's "sound placers" with a filigree extract of details and a wonderful understanding of the pedal-colorful means of the piano; it is a "masterpiece of art, embodied in the sounds of "sea plein air" (Delson, 1961, p. 19).

The second part of the Sonata (Presto) was written first; its "impressionistic nocturne" (V. Delson [ibid.]) was thought by the composer as a prelude to the sonata allegro (based on the model of Beethoven's "Moonlight sonata", but without the middle intermedia part). Presto music is permeated with a sense of impetuous continuous movement, consisting of "endless wave-like phrases", giving the impression of "restless, sad striving, ups and downs, heaves and drops" (Meskhishvili, 1981, p. 39).

Despite the contrast with Andante, Presto in many ways continues its line, which is confirmed by the presence in its texture of soft, smoothing echoes, attenuations at the end of "oncoming waves", and most importantly - the continuing improvisation of presentation" (Delson, 1961, p. 19-20). Presto's thematicism is derived from Andante, it refers to both themes of the sonata exposition, pianistically solved in compliance with the rule of combining synchronicity and asynchrony in the parts of the pianist's hands. One of them is based on the supporting positions of the nearest sounds, while the other hovers above the keyboard (in the theme of the main part, the supports are given in the left-hand part, and in the secondary part, in the pianist's right hand).

The general romantic spirit of the Second "sea" sonata, anticipating at the same time the ecstaticism of its sonata-piano poem (since the Fifth sonata O. Scriabin did not write any more cyclic sonatas), outstanding pianists translate in their interpretations, using their own creative intentions. Thus, S. Richter tends to emphasize the classicist origins of Scriabin's pianism, highlighting even Beethoven's notes in it. This is reflected in the almost unrestrained manner of performing polyphonic harmonic themes, the use of a typically Russian manner of "singing the piano" in episodes of lyrical content, with a minimum of free rubato in both parts. The pianist adheres to the edition of K. Igumnov, where the use of rubato is based on purely technical aspects and is used to emphasize low bass and register "overshoots" over long distances.

V. Ashkenazy's version differs from Richter's one with emphasizing romantic freedom, but observing its connection with the classicist fundamental principle. The pianist divides the Sonata into two contrasting figurative spheres, treating the first part as a lyrical landscape, and the second part as a dramatic one. The performing means are built accordingly: the illusory duality of the "landscape" of the first part is embodied with the help of numerous rubato and additional dynamic "forks"; in the second part, the combination of Schumann's impulse in active themes and Chopin's psychologism in reminiscences of the Andante themes prevails, which allows us to define this interpretation as a mixed, classic-romantic.

The Ninth sonata is, on the one hand, a complete antipode to the Second one, and on the other hand, it is a natural result of the evolution of Scriabin's sonata-piano thinking towards a direct reflection of the philosophical ideas of solepticism and mysteriously colored symbolism in the musical-linguistic concept of "harmony of melody".

It seems that among ten sonatas by O. Scriabin it is the pair "Second - Ninth" that is an indicator of "milestone", meaning a combination of continuity and renewal. In both works A. Scriabin remains a romantic with a "fervent imagination", with his "maximalism of the beautiful" and yet they are different just as "the decades of their birth are different" (Gakkel, 1988, p. 142-143).

The Ninth Sonata, op. 68, was created in 1913 and was performed for the first time in Moscow by the author himself. It is an "evil scherzo", about which O. Scriabin himself wrote that in it he "came into contact with the satanistic things more deeply than ever before," calling this 
sonata "disastrous"; contemporaries at the same time called the Ninth sonata the "black mass" as opposed to the Seventh one, which the author himself called the "white mass" (Meskhishvili, 1981, p. 173).

According to the compositional decision, the Ninth sonata is a one-part poem form, built according to the classical sonata model. Here the technique of "melody harmony", found by A. Scriabin in the Fifth sonata, is already fully observed. However, unlike the previous samples (the Sixth and subsequent sonatas, up to the Ninth), here it is presented not through one, but through several harmonic spheres, which is already reflected in the motives observed within the main themes - "the chromatic scale as the tonic basis of the $1^{\text {st }}$ and $2^{\text {nd }}$ elements of the main part and the ninth chord of the secondary one" (Meskhishvili, 1981, p. 3).

The dramatic concept of the Ninth sonata is based, as it is typical for the late O. Scriabin, on the concentration of intonational material, succinctly presented by key themes. The first theme, which acts as an epigraph, reproduces "a ghostly cold, real sound", a symbol of "fatal inevitability" [ibid.]. The second element of this theme is distinguished by coloristic sound painting in the form of major-minor "recolorings" of tones and "bell" tritones in the bass. From this theme, the through development of the material begins, semantically directed from "light to darkness".

The most indicative in this regard is the development, combined with the beginning of the reprise, where "the demonic whirlwinds of the main theme completely subdue the secondary one, acquiring the character of an ominous march, accompanied by bell chimes of an aggressively triumphant nature" (Razumeiko, 2007, p. 138). The Sonata ends with a coda repeating the original sphinx theme, which is ultimately left without decoding.

For performing interpretations of the Ninth sonata, it is especially important to feel the harmonic timbre colors presented sequentially, in the alternation of themes-images and, at the same time, in their polyphonic overlay. The melodic side of intonation here is inert in itself and appears only in conditions of harmonic lighting, which is distinguished by a variety of dynamic and articulatory elements fused together in a textured vertical. In such conditions, the rhythm built in the Ninth sonata on a single metric "grid" in the form of an accelerated marching size $4 / 8$ acts as the basis of performing shaping. In addition, O. Scriabin's syntactic structures always gravitate towards squareness, which allows the performer of the Ninth sonata to find another stabilizing factor in the conditions of the continuous fluidity of the form.

The main performing problem in the Ninth sonata is created by its texture. Being "uniform in type, it is detailed from the very beginning" (Meskhishvili, 1981, p. 190). In essence, O. Scriabin here creates a new type of texture "fragile, refined, consisting of intonations elusive in terms of the subtlety of color" [ibid.]. As a result of the polyphonic stratification of the vertical, Sonata No. 9 contains from three to six layerslines, united in a common piano score. Such a texture, in principle, is not differentiated into relief and background, which act in an ambivalent ratio. The main thing for the performer in every single moment of the sound is to create the effect of textured depth, achieved by means of dynamics, agogics and articulation. This effect associated with the spatial opposition "further closer" was programmed by O. Scriabin in the text of the Ninth sonata, an example of which are the sources of low frequencies - trills, rehearsals on one sound, presented in the connecting part and at the beginning of development.

The strictly thought-out logic of texture development allows the performer to divide this Sonata into two phases - exposure and development, which is indirectly related to the figurative program; the first phase is not yet a "misfortune", but its premonition, the second is a "come true premonition", "evil whirlwinds triumph" (words of O. Scriabin himself) (Meskhishvili, 1981, p. 191).

Despite the textured layering, the Ninth sonata is quite comfortable in terms of pianism: A. Scriabin as a pianist takes into account the possibilities of stretching the fingers of the performer's hands, maintaining a stable balance of synchronicity and asynchrony in the parts (support in one of them compensates for the "flight" of the other).

Of great importance for deciphering the figurative content and compositional form of the Ninth sonata is the complex of the author's remarks presented in its text - the "expressive continuum", which determines the "quality, measure and level of the strength of inner experience", the plan-algorithmic embodiment 
of the "personal, meaning of reality" in intonation artistic flow, "the quality of its impact on the perception of the listener" (Sokol, 1996, p. 9).

The directions proposed by O. Scriabin are divided into two groups - general and specific. They complement each other, acting in a complex: the designation of tempo and dynamics are accompanied by the characteristics of imagery. For example, in the epigraph theme, it is mysterieusement murmure ("mysteriously whispering"), complementing the tempo designation moderato quasi andante; to the theme of the side part, along with the new dynamic nuance of mezzo forte, the general remark avec unelangueur nassante ("with incipient yearning") is prefaced. Figurative remarks in French are given by the author in the expositional phase of the development of the form, and in the developmental part the music already speaks for itself, for which the usual Italian Alla marcia is enough.

The Ninth sonata is one of the most complex compositions in the world of sonata and piano literature. It is unique even for the O. Scriabin's style, since it is built according to a special logic of the germination of an intonational-genetic archetype, which has in its origins the intonation of spells, witchcraft and mysticism. Along with such "mysteriousness" (and largely thanks to it), the Ninth sonata opens up a wide field for various performing interpretations (O. Scriabin himself urged that this Sonata should "not be played", but "conjured" (quoted from Delson, 1961, p. 46)).

This is how the author himself played the Ninth sonata, using, according to the memoirs of L. Sabaneev (Meskhishvili, 1981, p. 241), numerous deviations from the rhythmic "grid". The interpreters of this Sonata as a whole do not allow themselves such "liberties", demonstrating "less rupture of rhythm than that of the authorperformer" (Dragulyan, 2009, p. 9). This is reflected in different ways in the performing versions proposed by such outstanding masters as V. Sofronitsky and V. Horowitz. Their interpretations reflect two opposite verses of this piano "black mass", which can be defined in terms of performance as romantic, emotional and playful (V. Sofronitsky) and classic, more objective, as if theatricalized (V. Horowitz).

$\mathrm{V}$. Sofronitsky is one of the most authoritative "scriabinists", not to mention his primacy in the performance of the entire macro-cycle, carried out in the late 1930s in one of the historical concerts.

Treating the O. Scriabin's sonatas, V. Sofronitsky sees in their forms the concentration of expression and the laws of musical logic "as impetuses for artistic fantasy" (Gakkel, 1988, p. 100). These common features of romantic pianism of V. Sofronitsky are combined with his individual and personal characteristics "nervous elation, mental-emotional intensity, sharpness of contours", [ibid.], Which was fully manifested in the interpretation of the Ninth sonata. As a romantic pianist V. Sofronitsky proceeds from the general foundations of O. Scriabin's sonata pianism with its ecstaticism and poetic fantasy, while paying less attention to the unique features of this particular work, which does not mean, however, ignoring them.

This is most obviously manifested through the timbre-rhythmic transformations of the material, differentiated not vertically, but horizontally, in the plasticity of movement, the dimensional character of which is constantly disturbed by rubatism and creates an additional "agogic score" in a general compositional form. This is most clearly presented in the interpretation of the first theme, the expression of which grows on a scale from a quiet and measured, "lulling" rhythm of a spell to sharp outbursts of pretentiousness, in order to be repeated further within the framework of a new wave in the development of a texture-thematic complex (meaning the theme side part, where the processes of dynamization of V. Sofronitskiy turn out to be inverse in relation to the main theme).

In the developmental phase designated by O. Scriabin as Alla Marcia, the pianist noticeably reduces rubato, focusing on dynamic contrasts in the execution of dotted and triplet rhythm formulas merging into a single sound stream. After the culmination reached - the highest point of the sound "curve", the "whirlwinds" of codes suddenly interrupt, subside: the pianist, as it were, "whispers the spell" again, performing the doomed and detached sounding themeepigraph.

The version of the Ninth sonata, proposed by V. Horowitz, follows from his general idea of the "image" of the piano, which has developed under the influence of the "artistic individuality of the pianist, passion for vocal art, the orientation of the performing act towards 
the public", which makes it possible to achieve "ensemble solution of texture, expressive relief intonation, fine phrasing, convexity and clarity of the smallest details; emotional fullness and colorfulness of sound when using a wide range of dynamic nuances (from intimate $p p p$ to the effect of orchestral tutti) and their lightning-fast change" (Sukhlenko, 2011, p. 8). V. Horowitz also manifests these individual features in his interpretation of the Ninth sonata, interpreting its texture as a set of plans of sound intensity (this is how E. Nazaikinsky defines the depth coordinate of the texture (Nazaikinsky, 1982, p. 73).

In contrast to V. Sofronitsky, V. Horowitz focuses on the vertical of the "piano score", highlighting all the elements that will become dominant in the formation of themes in the articulatory-dynamic way. This is especially indicative for the first phase of the development of the Sonata music, where the pianist seems to admire the colors and lines of a multi-layered musical fabric, trying to give brief motifspatterns, from which the entire thematic of the "black mass" is built, even some vocals coming from the Russian.

Thanks to this, the development-reprisal section of the Sonata (Alla marcia) as interpreted by $\mathrm{V}$. Horowitz sounds not just like an "explosion", but is perceived as an intonationally derivative of both themes of the exposition, which O. Scriabin himself suggested not to play, but to "conjure". Unlike V. Sofronitsky, V. Horowitz's dynamic shades tend to change the subito, even where there are author's crescendo and diminuendo remarks. As a result, the Ninth sonata by $\mathrm{V}$. Horowitz acquires the features of theatrical representation, which significantly distinguishes it from the interpretation of V. Sofronitsky, for whom the main thing was the principle of recreating the gradations of emotional-psychological subjective expression.

Conclusions from this study. The comparative analysis of two stylistically milestone sonatas by A. Scriabin, conducted in this article, together with their performing versions presented by S. Richter and V. Ashkenazy (Second sonata) and V. Sofronitsky and V. Horowitz (Ninth sonata), allows us to draw the following conclusions:

1) these works represent two versions of the Scriabin's musical language - romantic tonality with a diatonic dissonant basis (the first of the sonatas) and the principle of harmony melody found and implemented by the composer on the basis of the grandiose "Mystery" concept (the second of them);

2) both sonatas demonstrate in many respects the polar ideological and artistic attitudes of A. Scriabin: in the Second sonata it is a romantic landscape-mood filled with vague premonitions of future changes; in the Ninth one, the musical concept of the "black mass" is presented, personifying evil as the antithesis to mystery ecstaticism, flight to the "starry worlds" as the central theme of O. Scriabin's work;

$3)$ both sonatas demonstrate the evolution of O. Scriabin's piano writing in the direction from the Schumann-Chopin's technique of interchangeability of relief and background to the complete dissolution in a single sound texture of thematically significant motifs, combined vertically and horizontally and differentiated in depth;

4) the performing versions of both sonatas, presented by outstanding masters of world pianism, demonstrate the aesthetic symbiosis of the Scriabin's composer-performing standard and the stylistic intentions of the interpreters, each of which finds its individualized solution in the multidimensional world of intonations of Scriabin's music.

Prospects for further researches on the topic stated in this article are seen in expanding the range of analyzed performing versions of the Second and Ninth Scriabin's sonatas, including their latest reading by representatives of different national schools, which will enrich our understanding of the sonata-piano style of the great Russian master.

\section{References}

Alschwang, A. (1973). Life and work of A. N. Scriabin. Moscow: Nauka. [In Russian].

Asafiev, B. (1930). Russian music of the Republic of Tatarstan at the beginning of the XIX century. Moscow, Leningrad: ACADEMIA. [In Russian].

Gakkel, L. (1988). Piano sonatas by A. N. Lviv: Sovetsky kompozitor. [In Ukrainian].

Gakkel, L. (1988). In memory of $V$. Sofronitsky. Lviv: Sovetsky Kompozitor. [In Ukrainian].

Delson, V. (1961). Scriabin's Piano Sonatas. Moscow: Nauka. [In Russian].

Drahulian, V. V. (2009). Artistic and philosophical ideas of A. N. Scriabin and their development in the music of the XX century (Extended abstract of dissertation of the Candidate of the History of Art: 17.00.03). Kharkiv. [In Ukrainian]. 
Meskhishvili, E. (1981). Scriabin's Piano Sonatas. Moscow: Sovetsky kompozitor. [In Russian].

Nazaikinskii, E. V. (1982). Logic of musical composition. Moscow: Muzyka. [In Russian].

Pankratov, S. P. (1977). Texture in the piano works of Scriabin (Extended abstract of dissertation of the Candidate of the History of Art: 17.00.03). Kyiv. [In Ukrainian].

Razumeiko, I. (2007). Starry worlds of one-part sonatas by A. N. Scriabin (No. 5-10). Kyivske muzykoznavstvo: collection of articles. Kyiv Municipal Academy of Music named after R. M. Glier. [In Ukrainian].

Rubtsova, V. (1989). Alexander Nikolaevich Scriabin. Moscow: Muzyka. [In Russian].

Sokol, O. V. (1996). Stylistics of musical speech and terminological remarks (Extended abstract of dissertation of the Doctor of the History of Art: 17.00.03). Kyiv. [In Ukrainian].
Sukhlenko, I. Y. (2011). Performance style of Volodymyr Horowitz in the development of romantic tradition (Extended abstract of dissertation of the Candidate of the History of Art: 17.00.03). Kharkiv. [In Ukrainian].

Tyshko, S. V. (1993). The problem of national style in Russian opera: Glinka, Mussorgsky, RimskyKorsakov: research. Kyiv: Muzinform. [In Ukrainian]

Kholopova, V. N. (2000). Music as a kind of art: teaching guide. St. Petersburg: Lan. [In Russian].

Cherednichenko, T. (1993). The ideas of Yu. N. Kholopov about the philosophy of music. Moscow: LAUDAMUS. [In Russian].

Надійшла до редколегії 13.09.2020 